\begin{tabular}{|l|l|l||}
\hline \multicolumn{2}{|c|}{ PublisherInfo } \\
\hline \hline PublisherName & $:$ & BioMed Central \\
\hline \hline PublisherLocation & $:$ & London \\
\hline \hline PublisherImprintName & $:$ & BioMed Central \\
\hline \hline
\end{tabular}

\title{
SLE and Dnase1-deficient mice
}

\begin{tabular}{|l|l|l||}
\hline \multicolumn{2}{|c|}{ ArticleInfo } \\
\hline \hline ArticleID & $:$ & 175 \\
\hline \hline ArticleDOI & $:$ & $10.1186 /$ ar-2000-66821 \\
\hline \hline ArticleCitationID & $:$ & 66821 \\
\hline \hline ArticleSequenceNumber & $:$ & 132 \\
\hline \hline ArticleCategory & $:$ & Paper Report \\
\hline ArticleFirstPage & $:$ & 1 \\
\hline \hline ArticleLastPage & $:$ & 4 \\
\hline \hline & & RegistrationDate : 2000-6-21 \\
ArticleHistory & $:$ & OnlineDate \\
\hline \hline ArticleCopyright & $:$ & Current Science Ltd2000-21 \\
\hline \hline ArticleGrants & $:$ & \\
\hline \hline ArticleContext & $:$ & 130753311 \\
\hline \hline
\end{tabular}


Matthew Pickering, ${ }^{\text {Aff1 }}$

Aff1 Imperial College School of Medicine, England

\section{Keywords}

Antinuclear antibodies, Dnase1, glomerulonephritis, nucleosomes

\section{Context}

SLE is a multi-organ autoimmune disease characterised by the presence of circulating autoantibodies to both naked DNA and nucleosomes. The pathogenesis is primarily related to the deposition of such immune complexes in tissues, with subsequent inflammation and organ damage. A breakdown in the physiological mechanisms by which nuclear antigens (eg naked DNA and nuclear DNA-protein complexes) are removed during cell death may allow the development of an inappropriate immune response against such intracellular components. The removal of DNA from nuclear antigens released during cell death is thought to be mediated predominantly by Dnase 1, the major nuclease present in the serum and urine of both humans and mice. The development of Dnase1-deficient mice would therefore provide an ideal in vivo model to investigate these hypotheses further. To develop Dnase1-deficient mice by targeted gene deletion and to characterize the spontaneous phenotype.

\section{Significant findings}

Heterozygous Dnase1-deficient mice were fertile and healthy. Dnase1 mRNA was absent from parotid, kidney and small intestine RNA in homozygous mice and reduced to 50\% normal in heterozygotes. Zymograms showed that Dnase1 activity was absent from all organs of homozygous mice whilst activity was reduced in heterozygous animals when compared to wild-type mice. The incidence of antinuclear antibodies (ANAs) at 8 months in wild-type, heterozygous and homozygous animals was 15,48 and $56 \%$ for male mice and 35,65 and $73 \%$ for female mice respectively. Homozygous female mice had a significantly greater incidence of high-titre ANAs than wild-type controls. In both male and female Dnase1 deficient mice high-titre ANA positive sera contained antibodies against nucleosomes and ssDNA, whilst only female sera had antibodies to dsDNA. The incidence of glomerulonephritis at 8 months in wild-type, heterozygous and homozygous animals was 0 , 15 and $19 \%$ for male mice and 12, 19 and 31\% for female mice respectively. In Dnase1-deficient mice with glomerulonephritis, deposition of $\operatorname{IgG}$ and complement was demonstrated along the glomerular basement membrane. Some Dnase1-deficient mice were also found to develop perivascular leukocyte infiltration in the kidney and splenomegaly. Four patients with SLE and glomerulonephritis were 
demonstrated to have significantly lower serum Dnase 1 activity than healthy controls and patients with non-SLE nephritis.

\section{Comments}

This very interesting study supports the hypothesis that the failure to remove DNA-protein complexes during cell death may result in antinuclear autoimmunity and the development of a systematic lupus erythematosus (SLE)-like illness. The relationship between defective antigen clearance and spontaneous autoimmunity has now been observed in several mutant mouse strains. Mice deficient in complement C1q, serum amyloid P component, IgM and Dnase1 appear to have defects in the clearance of apoptotic cells, chromatin, effete cells and DNA-protein complexes respectively and all develop spontaneous autoimmunity. Human Dnase1, currently used in the treatment of cystic fibrosis, has already been safely administered intravenously to lupus patients but no changes in serum markers of disease activity were seen. This study provides further support for the development of therapeutic strategies that enhance the safe clearance of cell debris in SLE.

\section{Methods}

Dnase1-deficient mice were generated by deletion of the entire locus using a typical replacement vector. Confirmation of successful gene targeting was confirmed at the DNA and RNA level using Southern and northern blotting respectively. Dnase1 activity was assessed using zymograms in which various protein extracts were run on SDS-polyacrylamide gels containing calf thymus DNA. After electrophoresis, the proteins were renatured for $16 \mathrm{~h}$ and then stained using ethidium bromide. Dnase 1 activity was assessed by a lack of ethidium bromide staining due to hydrolysis of the co-polymerised calf DNA. Antinuclear antibodies were detected by indirect immunofluorescence and serum dilutions of more than 1/100 were considered positive. Antibodies to ssDNA, dsDNA, Sm antigen, histones and ribosomal P-proteins were measured by ELISA. Histological analysis was performed using standard techniques and glomerular changes scored blindly using a severity scale of grade 0 to 4 .

\section{Additional information}

Further discussion can be found in the news and views article by Walport et al, Nat Genet 2000, 25:135-136. 


\section{References}

1. Napirei M, Karsunky H, Zevnik B, Stephan H, Mannherz HG, Moroy T: Features of systemic lupus erythematosus in Dnase1-deficient mice. Nat Genet. 2000, 25: 177-181.

This PDF file was created after publication. 